\title{
Conicocassis, a new genus of Arcellinina (testate lobose amoebae)
}

\author{
Nawaf A. Nasser and R. Timothy Patterson
}

\begin{abstract}
Superfamily Arcellinina (informally known as thecamoebians or testate lobose amoebae) are a group of shelled benthic protists common in most Quaternary lacustrine sediments. They are found worldwide, from the equator to the poles, living in a variety of fresh to brackish aquatic and terrestrial habitats. More than 130 arcellininid species and strains are ascribed to the genus Centropyxis Stein, 1857 within the family Centropyxidae Jung, 1942, which includes species that are distinguished by having a dorsoventral-oriented and flattened beret-like test (shell). Conicocassis, a new arcellininid genus of Centropyxidae differs from other genera of the family, specifically genus Centropyxis and its type species C. aculeata (Ehrenberg, 1932), by having a unique test comprised of two distinct components; a generally ovoid to subspherical, dorsoventral-oriented test body, with a pronounced asymmetrically positioned, funnellike flange extending from a small circular aperture. The type species of the new genus, Conicocassis pontigulasiformis (Beyens et al., 1986) has previously been reported from peatlands in Germany, the Netherlands and Austria, as well as very wet mosses and aquatic environments in High Arctic regions of Europe and North America. The occurrence of the species in lacustrine environments in the central Northwest Territories extends the known geographic distribution of the genus in North America considerably southward.
\end{abstract}

Nawaf A. Nasser. Department of Earth Sciences, Carleton University, 1125 Colonel By Drive, Ottawa, Ontario, K1S 5B6, Canada. Nawafnasser@cmail.carleton.ca

R. Timothy Patterson. Department of Earth Sciences, Carleton University, 1125 Colonel By Drive, Ottawa, Ontario, K1S 5B6, Canada. Tim.Patterson@carleton.ca

Keywords: Arcellinina; Canada; Conicocassis gen. nov.; new genus, Northwest Territories; Quaternary; testate lobose amoebae

Submission: 5 February 2015 Acceptance: 28 August 2015

http://zoobank.org/DF1CB6ED-E5A9-4400-8FF2-4E7F5846EF78

Nasser, Nawaf A. and Patterson, R. Timothy 2015. Conicocassis, a new genus of Arcellinina (testate lobose amoebae).

Palaeontologia Electronica 18.3.46A: 1-11

palaeo-electronica.org/content/2015/1323-new-genus-of-arcellinina

Copyright: Paleontological Society September 2015 


\section{INTRODUCTION}

Superfamily Arcellinina, also known as testate lobose amoebae (e.g., Macumber et al. 2014) or thecamoebians (e.g., Vázquez-Riveiros et al., 2007), are a group of well-preserved benthic protists common in most Quaternary lacustrine deposits (Loeblich and Tappan, 1964; Medioli and Scott, 1983; Scott and Medioli, 1983). This cosmopolitan group is found worldwide from the tropics to polar regions, living in a wide range of moist freshwater environments (e.g., lakes, rivers and peatlands: Ogden and Hedley, 1980; Medioli and Scott, 1983; Patterson et al., 1985; Medioli et al., 1990a; Medioli et al., 1990b; Patterson et al., 1996) as well as being found in low-salinity brackish habitats (Charman et al., 2000; Patterson and Kumar, 2002). The amoeboid body of the organism is protected by a beret- or sac-like test (shell) that is sometimes autogenous (secreted by the organism) and more commonly xenogenous (formed by agglutinating foreign materials like sand grains and/or diatoms frustules) (Patterson and Kumar, 2002). Although preserved arcellininid specimens are most common in Quaternary deposits, their fossil record extends through the Phanerozoic (Porter and Knoll, 2000) and into the Neoproterozoic (van Hengstum et al., 2007).
Centropyxidae Jung, 1942, a family within Arcellinina, includes the genus Centropyxis von Stein, 1857. Members of this family are distinguished by a chitinous, dorsoventrally symmetric test with a central to eccentric ventral aperture. Species and strains attributed to the genus Centropyxis are characterized by a generally flattened beret-like, discoid or oval test with a sub-terminal to central, circular to ovate, invaginated aperture located on the ventral side. The test is colorless to brown and may or may not be covered by agglutinating material, which varies from mineral grains to organic debris, particularly diatom frustules. Additionally, the test may or may not be ornamented with spines of varying number and length. As noted by several authors, this broad generic description permits considerable latitude in the morphology of species that can be attributed to the genus (e.g., Leidy, 1879; Root, 1918; Deflandre, 1929; Medioli and Scott, 1983; Ogden, 1988; Wanner, 1999). Centropyxid species have mainly been distinguished by variation in test size and shape, aperture size and form, as well as the number and length of spines. Of the more than 130 species and strains identified, the descriptions for many are inadequate (Meisterfeld, 2002). A particular problem within this group is that some of the more poorly agglutinated species are quite delicate creating difficulties in imaging them, particularly under

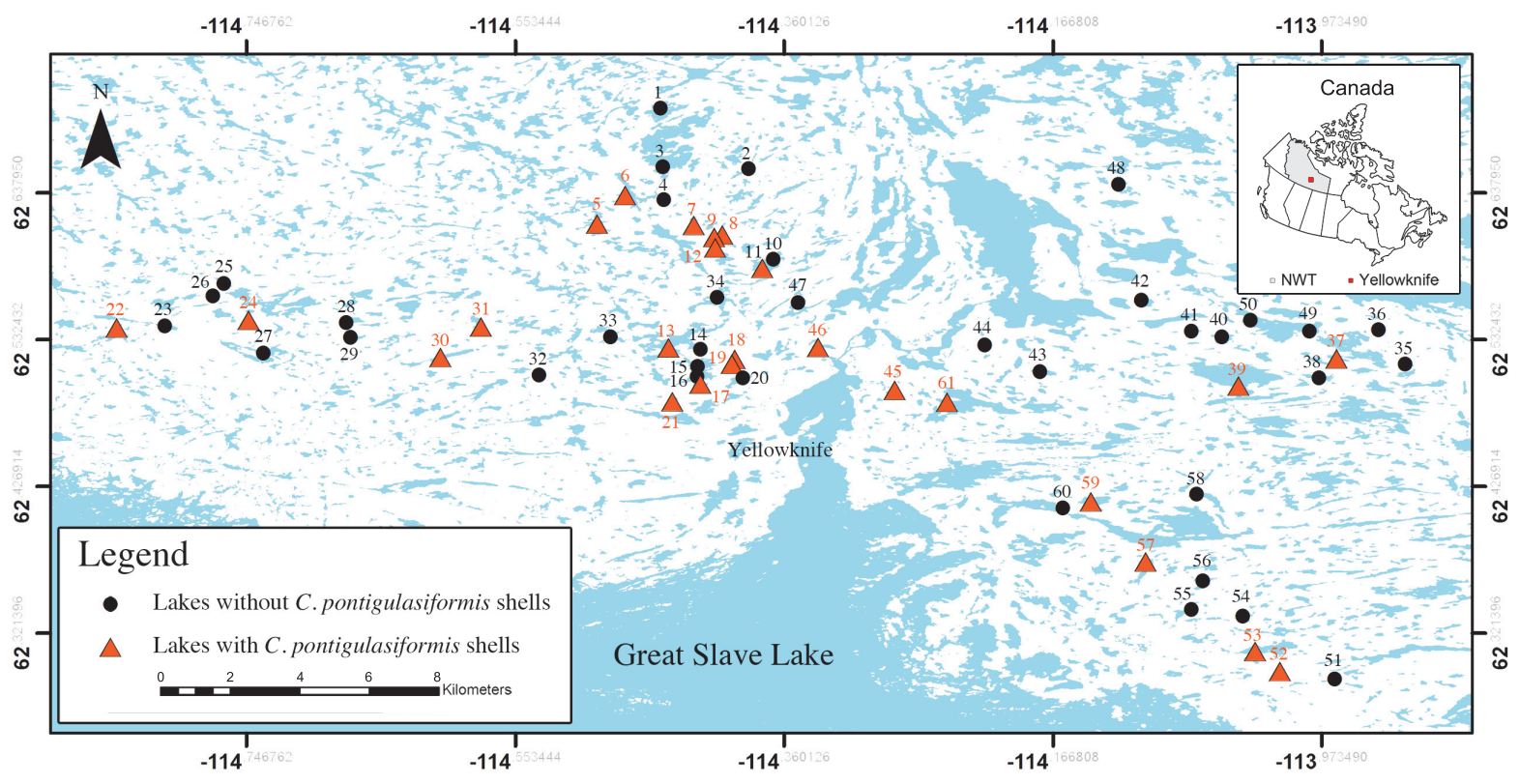

FIGURE 1. Map of the study region showing location of the sampled lakes (red triangles and black circles). The red triangles represent sample stations where Centropyxis pontigulasiformis was observed, while black circles characterize stations where the species was not detected. The numbers represent the sampling order, which corresponds to the sample identification codes shown in Table 1. 
a vacuum as required for most scanning electron microscopes, as well as in preserving type material (Lahr et al., 2008). Additional difficulties arise because some centropyxid taxa are characterized by considerable morphologic variation, for example Centropyxis aculeata (Ehrenberg, 1832), resulting in various phenotypes being erroneously attributed to separate taxa (Medioli and Scott, 1983; Lahr, personal comun., 2014).

A potentially valuable new tool to determine the validity and taxonomic position of centropyxid taxa is molecular systematics. In an analysis of five difflugid taxa, Gomaa et al. (2012) determined that the group was not monophyletic and that shell morphology closely correlated with genetic clades. Genetic research has also revealed that testate lobose amoebae are characterized by numerous morphologically identical cryptospecies, inhabiting geographically diverse environments (Mitchell and Meisterfeld, 2005; Alizon et al., 2008; Heger et al., 2013; Oliverio et al., 2014). Based on these results Patterson (2014) has suggested that even iconic arcellininid taxa such as Mediolus corona (Wallich, 1864), found living in a range of habitats from the equator to poles, may be comprised of several crypto taxa, the morphology of which may be the product of convergent evolution. Unfortunately, genetic analysis of Arcellinina is still in its early stages. Only few studies have been successfully carried out on arcellininid taxa (e.g., Nikolaev et al., 2005; Lara et al., 2008; Kudryavtsev et al., 2009; Gomaa et al., 2015) due to the difficulty of sequencing protists with agglutinated tests. In addition to genetic analyses, novel morphometric approaches (e.g., Macumber et al., 2014 in an analysis of Difflugia protaeiformis Lamarck, 1816 strains) may provide an additional methodology to determine the systematic placement of taxa.

As part of a project mandated to determine the utility of arcellininids as a tool to monitor arsenic contamination in lakes from the Yellowknife region of the Northwest Territories, Canada, we have identified and quantified populations of Centropyxis pontigulasiformis Beyens et al., 1986, which is present in statistically significant numbers (between 4 and 62 shells) in many lakes within the studied region (Figure 1; Table 1; NAN, unpublished data; Patterson and Fishbein, 1989). This species was originally described from very wet terrestrial mosses, as well as from subaqueous mosses on Edgeøya (Edge) Island $\left(77^{\circ} 45^{\prime} \mathrm{N}, 2^{\circ}\right.$ $\left.30^{\prime} \mathrm{E}\right)$ in the Norwegian Svalbard archipelago (Beyens et al., 1986). The species was subsequently reported from both wet terrestrial mosses and aquatic environments at high latitude throughout the Svalbard archipelago, West Greenland, islands in the Canadian Arctic Archipelago and the north coast of Alaska (Beyens and Chardez, 1995). Based on these occurrences the species was initially determined to be restricted to Arctic environments. However, specimens attributed to $C$. pontigulasiformis have also been identified in samples obtained from peat bogs in Het Hol, Netherlands, Rotes Wasser, Germany and Tirol, Austria (Siemensma, 2015). The occurrence of $C$. pontigulasiformis in lakes from the Yellowknife area of the central Northwest Territories significantly extends the known geographic distribution of the species southward in North America (Figure 1; Table 1).

Centropyxis pontigulasiformis is one of the most distinctive arcellininid species. Atypical of arcellininid species and strains of the genus Centropyxis, the test is comprised of two distinctive components: a semi-spherical to spherical main test body and a relatively large, open ended, conical, visor-like flange that extends from a small circular aperture (Figure 2). Aside from being unilocular, the species bears no similarity to $C$. aculeata, the type species of the genus Centropyxis (Figure 3), or any other species attributed to the genus. However, the tests of $C$. pontigulasiformis maintain the dorsoventral symmetry characterizing the family Centropyxidae. We, therefore, propose that $C$. pontigulasiformis be recognized as the type species of a new genus within the family Centropyxidae.

\section{MATERIALS AND METHODS}

\section{Field Work}

Sixty-one surface sediment samples were collected from 59 lakes from the Yellowknife region in August of 2012. The samples were collected along four, $\sim 40 \mathrm{~km}$ long transects (north, south, east and west of the city of Yellowknife) from a float helicopter using an Ekman grab sampler (Figure 1). The onboard helicopter GPS system was used to record the position of each station (Table 1). The depth of each sampled lake was determined by deploying a commercial "fish finder" with bottom hardness indicator from a helicopter pontoon. Sample stations characterized by muddy substrates were preferentially sought out, as nutrient poor silt to sand substrates are generally characterized by depauperate allochthonous arcellininid populations (Patterson and Kumar, 2002). 
NASSER \& PATterson: NeW Genus of ARCELlinina

TABLE 1. Coordinates, quantitative arcellininid information and Shannon Diversity Index (SDI) values of the samples containing specimens of Centropyxis pontigulasiformis.

\begin{tabular}{|c|c|c|c|c|c|c|c|}
\hline \multirow{2}{*}{$\begin{array}{c}\text { Sample } \\
\text { ID }\end{array}$} & \multirow{2}{*}{ Transect } & \multirow[b]{2}{*}{ Lat. } & \multirow[b]{2}{*}{ Long. } & \multirow{2}{*}{$\begin{array}{c}\text { Total } \\
\text { Arcellininid } \\
\text { Counts }\end{array}$} & \multicolumn{2}{|c|}{ C. pontigulasiformis } & \multirow[b]{2}{*}{ SDI } \\
\hline & & & & & $\begin{array}{c}\text { Absolute } \\
\text { Abundance }\end{array}$ & $\begin{array}{c}\text { Relative } \\
\text { Abundance (\%) }\end{array}$ & \\
\hline BC 5 & North & 62.6158 & -114.4944 & 338 & 4 & 1.1834 & 1.96 \\
\hline $\mathrm{BC} 6$ & North & 62.6362 & -114.4744 & 184 & 2 & 1.087 & 2.36 \\
\hline $\mathrm{BC} 7$ & North & 62.6147 & -114.4248 & 226 & 2 & 0.885 & 2.07 \\
\hline $\mathrm{BC} 8$ & North & 62.608 & -114.4045 & 317 & 13 & 4.1009 & 2.57 \\
\hline BC 9 & North & 62.6063 & -114.4103 & 290 & 5 & 1.7241 & 2.6 \\
\hline BC 11 & North & 62.584 & -114.3756 & 303 & 1 & 0.33 & 2.1 \\
\hline BC 12 & North & 62.5987 & -114.4096 & 232 & 6 & 2.5862 & 2.23 \\
\hline BC 13 & North & 62.5269 & -114.443 & 265 & 1 & 0.3774 & 2.16 \\
\hline BC 17 & North & 62.5007 & -114.4201 & 291 & 2 & 0.6873 & 1.53 \\
\hline BC 18 & North & 62.5184 & -114.3956 & 213 & 4 & 1.8779 & 1.84 \\
\hline BC 19 & North & 62.5152 & -114.3974 & 222 & 9 & 4.0541 & 1.7 \\
\hline BC 21 & North & 62.4882 & -114.4405 & 250 & 3 & 1.2 & 2.62 \\
\hline BC 22 & West & 62.5411 & -114.84 & 143 & 41 & 28.6713 & 1.93 \\
\hline BC 24 & West & 62.5466 & -114.7452 & 176 & 2 & 1.1364 & 1.64 \\
\hline BC 30 & West & 62.5199 & -114.6072 & 264 & 1 & 0.3788 & 2.45 \\
\hline BC 31 & West & 62.5418 & -114.578 & 278 & 5 & 1.7986 & 2.37 \\
\hline BC 37 & East & 62.5189 & -113.9626 & 306 & 54 & 17.6471 & 1.89 \\
\hline BC 39 & East & 62.4992 & -114.0331 & 284 & 2 & 0.7042 & 2.12 \\
\hline BC 45 & East & 62.4962 & -114.2803 & 184 & 1 & 0.5435 & 2.25 \\
\hline BC 46 & East & 62.527 & -114.3357 & 296 & 62 & 20.9459 & 1.93 \\
\hline BC 52 & South & 62.2941 & -114.0033 & 266 & 2 & 0.7519 & 2.27 \\
\hline BC 53 & South & 62.3087 & -114.0213 & 239 & 2 & 0.8368 & 2.31 \\
\hline BC 57 & South & 62.3729 & -114.0998 & 264 & 1 & 0.3788 & 1.97 \\
\hline BC 59 & South & 62.4161 & -114.1392 & 287 & 44 & 15.331 & 1.94 \\
\hline BC 61 & South & 62.4876 & -114.2426 & 307 & 31 & 10.0977 & 2.11 \\
\hline
\end{tabular}



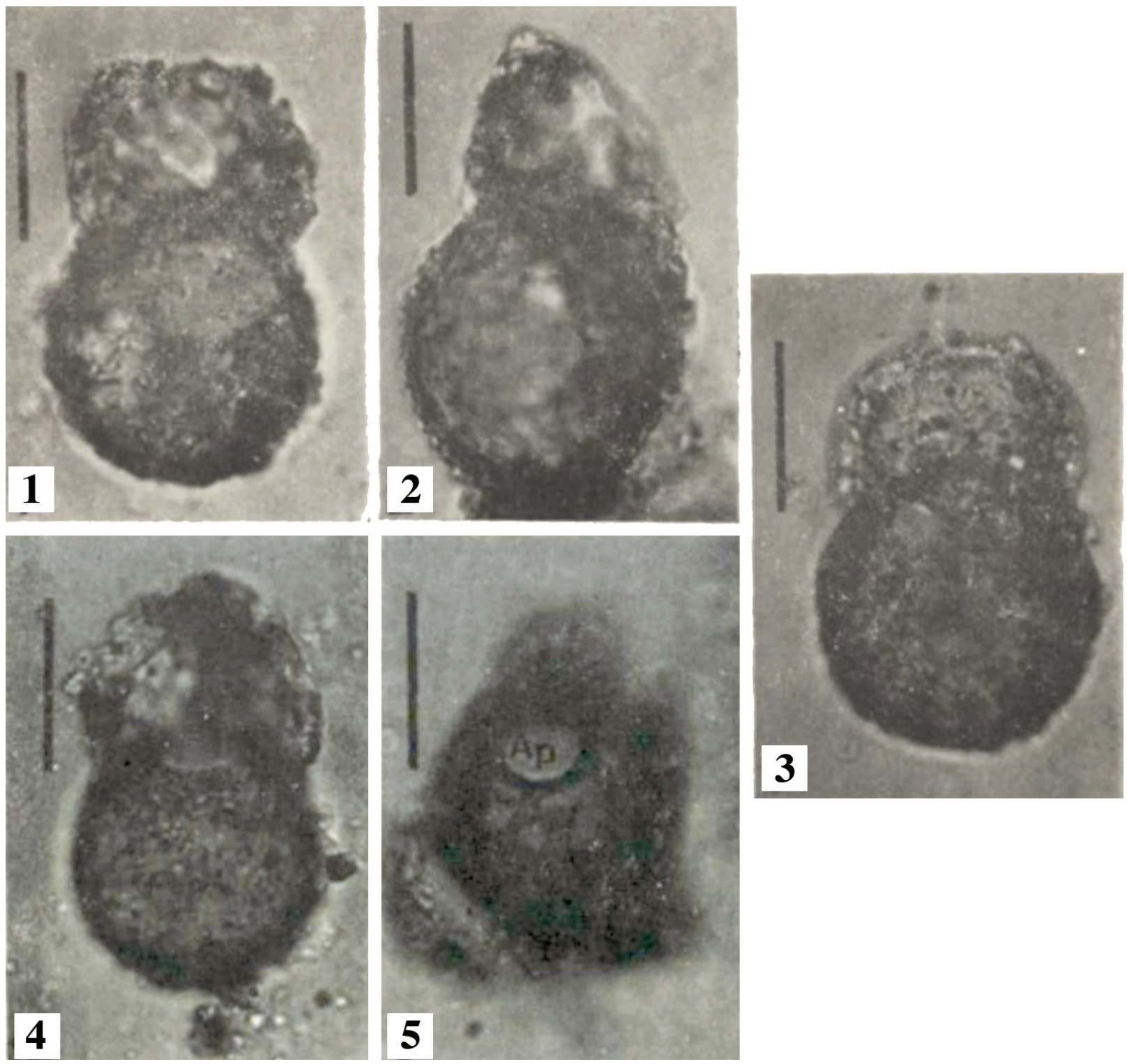

FIGURE 2. Light photomicrographs of the type illustrations of Centropyxis pontigulasiformis (as published by Beyens et al., 1986, plate 3, 1-5). 1, apertural view of the test; $\mathbf{2}$, lateral view of the test; $\mathbf{3}$, apertural view of the test; $\mathbf{4}$, apertural view of the test; and $\mathbf{5}$, a close-up on the circular aperture without the flange. The length of the scale bars represent $40 \mu \mathrm{m}$. Permission to reprint Beyens et al. (1986, plate 3, 1-5) was granted by Acta Protozoologica.

\section{Micropaleontological Analysis}

The upper $0.5 \mathrm{~cm}$ of sediment from each Ekman grab was retained for micropaleontological and geochemical analysis. A $2.5 \mathrm{cc}^{3}$ sub samples was separated for micropaleontological analysis. These samples were first wet sieved through a $297-\mu \mathrm{m}$ mesh to remove any coarse debris (e.g., coarse grains, grass and sticks) and subsequently passed through a 37- $\mu \mathrm{m}$ mesh to remove the claysize fraction and retain arcellininids. Samples were immediately placed in isopropyl alcohol and refrig- erated in order to avoid protoplasm decay. Prior to quantitative micropaleontological analysis the preserved sediment was subdivided into six aliquots using a wet splitter (after Scott and Hermelin, 1993). Each wet aliquot was then placed in a gridded Petri Dish and arcellininid specimens were counted using an Olympus SZH dissecting binocular microscope (at 7.5-64x magnification) until, whenever possible, a statistically significant number of specimens were quantified (Patterson and Fishbein, 1989). Identification of arcellininids primarily followed the descriptions and illustrations 

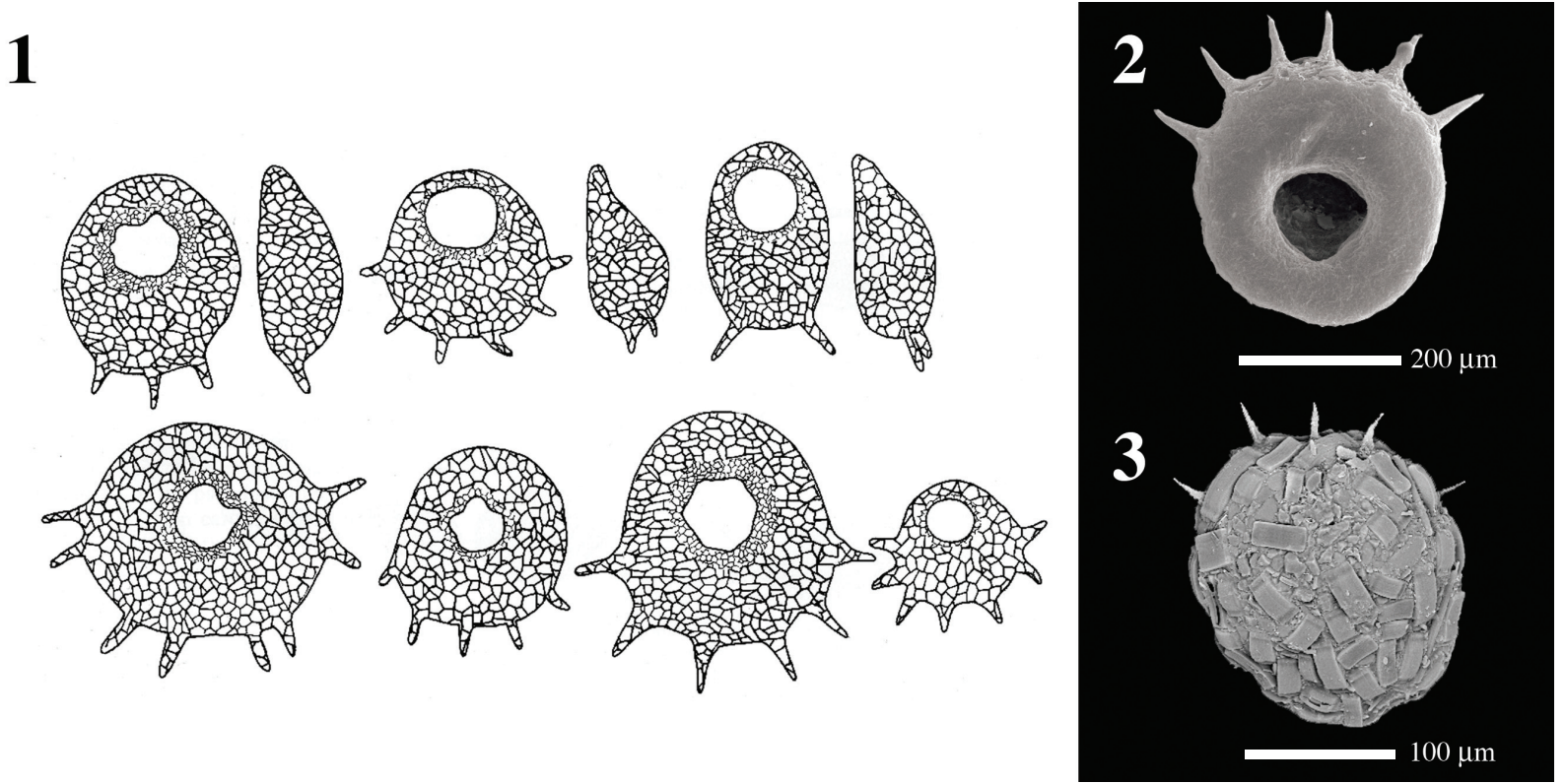

FIGURE 3. Specimens of Centropyxis aculeata (Ehrenberg, 1832), the type species of genus Centropyxis. 1, redrafted sketches of $C$. aculeata from Leidy (1879, plate 31) (modified after Medioli and Scott, 1983, figure 11) showing some of the typical morphotypes within the species. 2 and 3, scanning electron microscope of specimens from the lakes in the Yellowknife region, NT, Canada; ventral-apertural view showing the most common test morphology with semi-circular aperture and long spines extending from the fundus and very fine grained agglutination on ventral surface (2) and dorsal view showing xenogenous agglutination comprised both of diatom frustules and mineral grains (3).

found in various publications, notably Medioli and Scott (1983), Reinhardt et al. (1998), Roe et al. (2010), Patterson et al. $(2012,2013)$. Specimens of C. pontigulasiformis were identified in 25 lakes (Table 1). Light photomicrographs of arcellininids where taken using a Canon Rebel T1i, while Scanning electron microscope images were obtained using a Tescan Vega-II XMU VP scanning electron microscope at the Carleton University SEM facility.

\section{TAXONOMY}

Phylum AMOEBOZA (Lühe, 1913) Corliss, 1984

Subphylum LOBOSA Carpenter, 1861

Class TUBULINEA Smirnov et al., 2005

Subclass TESTACEALOBOSIA De Saedeleer, 1934

Order ARCELLINIDA Kent, 1880

Suborder ARCELLININA Haeckel, 1884

Superfamily DIFFLUGACEA Stein, 1859

Family CENTROPYXIDAE Jung, 1942

Genus Conicocassis gen. nov.

zoobank.org/CF0D9768-05CE-4703-9A7F-3B43521C2217

Type Species. Centropyxis pontigulasiformis Beyens, Chardez and De Bock, 1986.

Diagnosis. A genus of Centropyxidae characterized by dorsoventrally symmetric, ovoid to sub- spherical test typically comprised of agglutinated particles obtained from the environment, round aperture and diagnostic very large and asymmetrically oriented conical to funnel-like apertural flange extending from a small circular aperture.

Description. Test free; unilocular; ovoid to subspherical to spherical; subcircular in cross section; test dorsoventrally symmetrical in most cases; test wall comprised of agglutinated particles derived from mineral or biologic sources bound together with an organic cement; aperture circular; proportionately very large conical to funnel-shaped and typically asymmetrically oriented flange extends from aperture; broad apertural rim recurved inward and comprised of fine agglutinated grains.

Types and Occurrence. Very wet mosses and aquatic environments in High Arctic regions of Europe and North America; lacustrine environments in the Central Northwest Territories of Canada; and peatlands in Germany, the Netherlands and Austria.

Dimensions. Length: $90-150 \mu \mathrm{m}$; width: $50-100$ $\mu \mathrm{m}$. Main test body: $50-100 \mu \mathrm{m}$ across in all dimensions; funnel-shaped apertural flange: $25-50$ $\mu \mathrm{m}$ across.

Remarks. Many of the diagnostic test features characterizing members of the family Centropyxi- 


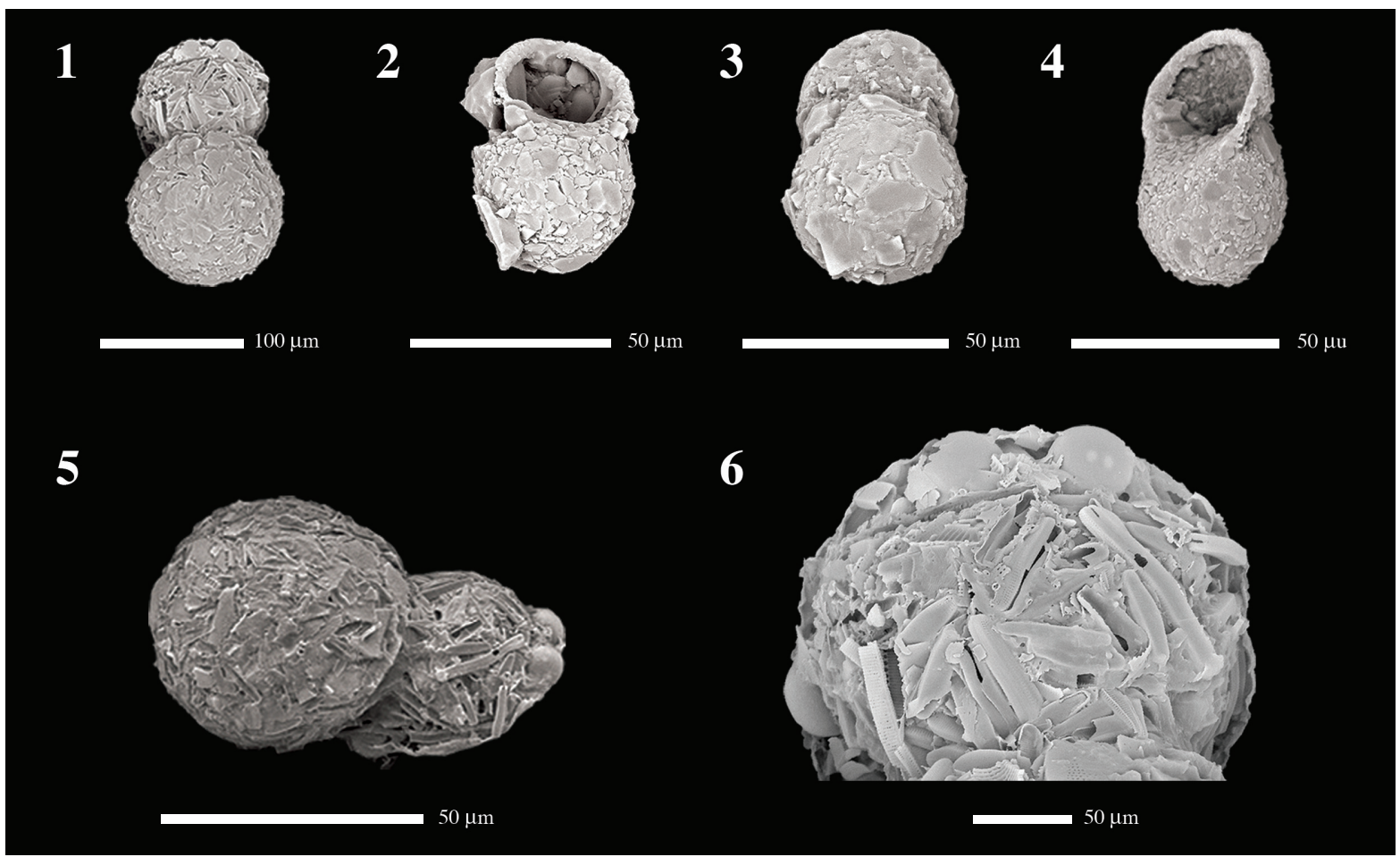

FIGURE 4. Specimens of Conicocassis pontigulasiformis gen. et comb. nov. from lakes in Yellowknife region, Northwest Territories, Canada. 1, dorsal view of a specimen from sample BC8 showing the distinct main test body and distinctive upper funnel-like flange; 2 , apertural view of a specimen collected from sample BC12 showing large aperture; 3, dorsal view of a specimen from sample BC12 with agglutination primarily comprised of large xenogenous particles; 4, oblique view of a test collected from sample BC37 showing orientation of large flange relative to apertural opening; $\mathbf{5}$, edge view of a specimen in sample BC12 showing the distinctive morphology of the main test body relative to asymmetric flange; and 6, a close-up of the flange of a specimen collected from sample BC12 clearly showing that pennate diatoms, pollen grains and mineral particles are important components of the agglutination of this specimen.

dae (e.g., dorsoventral symmetry, chitinoid test and circular to oval aperture) are maintained in the new genus, Conicocassis. Therefore, Conicocassis is recognized as a member of the family Centropyxidae along with the genus Centropyxis. However, the new genus is readily distinguished from Centropyxis in having a two-component test comprised of an ovoid to subspherical main body, and a relatively very large conical to funnel-like and asymmetrically positioned flange extending out from a small circular aperture. In contrast Centropyxis tests tend to be beret-like to discoidal shaped with an invaginated ventral aperture. Conicocassis differs from some taxa of Difflugia (e.g., D. urceolata Carter, 1864, and D. urens Patterson et al., 1985), which are also characterized by apertural rims, in that the rim surrounding the aperture of the new genus tends to be asymmetrically placed and in most cases is nearly as large as the main test body.

The lower test body of Conicocassis is ovoid or subspherical to spherical with a wall composed of polymorphous mineral particles within an organic matrix. The colorless to brown main test body is topped by a cone-like flange, which extends out from a small circular aperture. The cone-like flange is mostly embossed with broken, or intact, diatoms frustules and quartz particles (Figure 4), and appears to be nearly as large as the main test body if observed from the apertural view. In some cases, the flange may be characterized by coloration distinct from the main test body. The attachment area of the apertural flange to the main test body produces a pronounced constriction in the test wall that is particularly diagnostic.

A statistically significant number of Conicocassis specimens (between 4 and 62 shells) was quantified in 12 surface sediment samples (Table 1) that were collected from lakes in the Yellowknife region in 2012 (personal observation). In addition to the stark morphological differences between specimens from Conicocassis and Centropyxis, it was possible to identify distinctive ecological preferences between differences between these gen- 


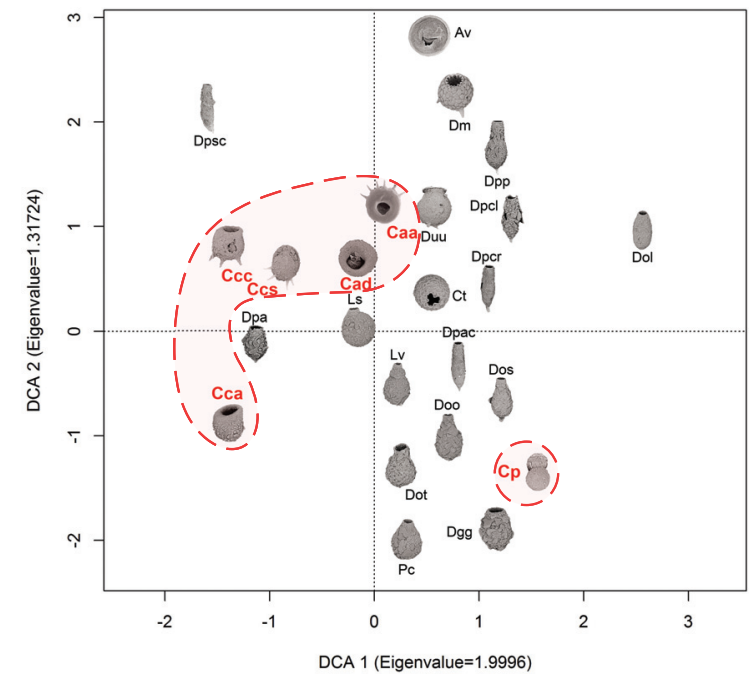

FIGURE 5. Detrended Correspondence Analysis (DCA) bi-plot based on species scores showing the faunal distribution of arcellininid species and strains in the Yellowknife region. Abbreviations: Av, Arcella vulgaris; Caa, Centropyxis aculeata "aculeata"; Cad, Centropyxis aculeata "discoides"; Cca, Centropyxis constricta "aerophila"; Ccc, Centropyxis constricta "constricta"; Ccs, Centropyxis constricta "spinosa"; $\mathrm{Cp}$, Conicocassis pontigulasiformis; Ct, Cucurbitella tricuspis; Dgg, Difflugia glans "glans"; Dol, Difflugia oblonga "lanceolata"; Doo, Difflugia oblonga "oblonga"; Dos, Difflugia oblonga "spinosa"; Dot, Difflugia oblonga "tenuis"; Dpa, Difflugia protaeiformis "amphoralis"; Dpac, Difflugia protaeiformis "acuminata"; Dpcl, Difflugia protaeiformis "claviformis"; Dpcr, Difflugia protaeiformis "curvicaulis"; Dpp, Difflugia protaeiformis "protaeiformis"; Dpsc, Difflugia protaeiformis "scalpellum"; Duu, Difflugia urceolata "urceolata"; Ls, Lesquereusia spiralis; Lv, Lagenodifflugia vas; Mc, Mediolus coron; Pc, Pontigulasia compressa.

era using multivariate analyses techniques like Detrended Correspondence Analysis (DCA) and Redundancy Analysis (RDA). The DCA results revealed Conicocassis plotting at a significant distance from the Centropyxis species and strains, which clustered closely together (Figure 5), indicating a fundamental difference in realized niche space for Centropyxis and Conicocassis. The RDA analysis results showed that Conicocassis is influenced by environmental variables associated with relatively healthy and productive environments (e.g., barium and phosphorous), whereas stress tolerant centropyxid taxa were most strongly associated with significant environmental stressors (e.g., elevated levels of arsenic; Figure 6).

Etymology. From the Latin Conicus, cone, conelike $+o$, connective vowel + Latin Cassis, helmet,

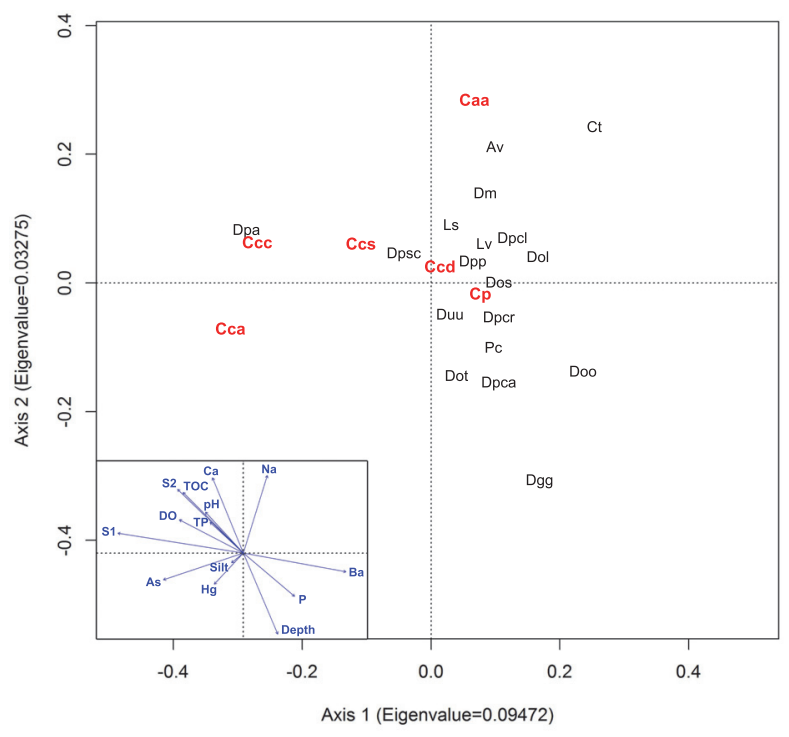

FIGURE 6. Redundancy Analysis (RDA) species-environment-sample tri-plot. Environmental variables (arrows) are shown in the inset to avoid a clutter. Abbreviations: As, arsenic; $\mathrm{Ba}$, barium; $\mathrm{Ca}$, calcium; $\mathrm{DO}$, dissolved oxygen; $\mathrm{Hg}$, mercury; $\mathrm{Na}$, sodium; $\mathrm{P}$, phosphorous; S1, S1 carbon; S2, S2 carbon; TOC, total organic carbon; TP, total phosphorous. See Figure 5 caption for other abbreviations.

with reference to the distinct shape of the pronounced apertural flange. The gender for this new genus is feminine.

Stratigraphic Range. Holocene.

\section{ACKNOWLEDGMENTS}

This research was supported by the Natural Science and Engineering Research Council (NSERC) Discovery Grant to RTP. Thanks are extended to A. Kumar for insightful discussions on Arcellinina taxonomy. Appreciation is extended to J.J. Wang, Nano Imaging Facility in Carleton University, for assistance in obtaining SEM images.

\section{REFERENCES}

Alizon, S., Kucera, M., and Janser, V.A.A. 2008. Competition between cryptic species explains variations in rates of lineage evolution. Proceedings of the National Academy of Sciences, 105:12382-12386.

Beyens, L. and Chardez, D. 1995. An annotated list of testate amoebae observed in the Arctic between the longitudes $27^{\circ} \mathrm{E}$ and $168^{\circ} \mathrm{W}$. Archiv für Protistenkunde, 146:219-233.

Beyens, L., Chardez, D., and De Bock, P. 1986. Some new and rare testate amoebae from the Arctic. Acta Protozoologica, 25:81-91. 
Carpenter, W.B. 1861. On the systematic arrangement of the Rhizopoda. Natural History Review, 1:456-472.

Carter, H.J. 1864. On Freshwater Rhizopoda of England and India with Illustrations. Annals Magazine of Natural History, 13:18-39.

Charman, D.J., Hendon, D., and Woodland, W. 2000. The Identification of Peatland Testate Amoebae. Quaternary Research Association Technical Guide no. 9, London.

Corliss, J.O. 1984. The Kingdom Protista and its 45 phyla. BioSystems, 17(2): 87-126.

Deflandre, G. 1929. Le genre Centropyxis Stein. Archiv für Protistenkunde, 67:322-375. (In French)

De Saedeleer, H. 1934. Beitrag zur Kenntnis der Rhizopoden: Morphologische und systematische Untersuchungen und ein Klassifkationsversuch. Mémoires du Musée Royal d'Histoire Naturelle de Belgique, 60:1-112. (In German)

Ehrenberg, C.G. 1832. Über die Entwicklung und Lebensdauer der Infusionsthiere, nebst ferneren Beiträgen zu einer Vergleichung ihrer organischen Systeme. Königliche Akademie der Wissenschaften zu Berlin Physikalische Abhandlungen, 1831:1-154. (In German)

Gomaa, F., Todorov, M., Heger, T.J., Mitchell, E.A.D., and Lara, E. 2012. SSU rRNA phylogeny of Arcellinida (Amoebozoa) reveals that the largest Arcellinid genus, Difflugia Leclerc 1815, is not monophyletic. Protist, 163:389-399.

Gomaa, F., Yang, J., Mitchell, E.A.D., Zhang, W.-J., Yu, Z., Todorov, M., and Lara, E. 2015. morphological and molecular diversification of Asian endemic Difflugia tuberspinifera (Amoebozoa, Arcellinida): A case of fast morphological evolution in protists? Protist, 166:122-130.

Haeckel, E. 1884. Ueber die Geometrie der Radiolarien (Promorphologie). In: Sitzungsber der Jenaischen. Gesellschaft für Medizin und Naturwissenschaften, vom 22. November 1883. (In German)

Heger, T.J., Mitchell, E.A., and Leander, B.S. 2013. Holarctic phylogeography of the testate amoeba Hyalosphenia papilio (Amoebozoa: Arcellinida) reveals extensive genetic diversity explained more by environment than dispersal limitation. Molecular Ecology, 22:5172-5184.

Jung, W. 1942. Südchilenische Thekamöben (aus dem südchilenischen Küstengebiet, Beitrag 10). Archiv für Protistenkunde, 95:253-356. (In German)

Kent, W.S. 1880. A Manual of the Infusoria: Including a Description of all Known Flagellate, Cilite, and Tentaculiferous Protozoa, British and foreign, and an account of the organization and affinities of sponges, 1. Bogue, London.

Kudryavtsev, A., Pawlowski, J., and Hausmann, K. 2009. Description and phylogenetic relationships of Spumochlamys perforate $\mathrm{n}$. $\mathrm{sp}$ and Spumochlamys bryora n. sp (Amoebozoa, Arcellinida). Journal Eukaryotic Microbiology, 56:495-503.
Lahr, D.J.G., Bergmann, P.J., and Lopes, S.G.B.C. 2008. Taxonomic identity in microbial eukaryotes: A practical approach using the testate amoeba Centropyxis to resolve conflicts between old and new taxonomic descriptions. Journal of Eukaryotic Microbiology, 55(5): 409-416.

Lamarck, J.B. 1816. Histoire naturelle des animaux sans vèrtèbres, tome 2. Verdièie, Paris. (In French)

Lara, E., Heger, T.J., Ekelund, F., Lamentowicz, M., and Mitchell, E.A.D. 2008. Ribosomal RNA genes challenge the monophyly of the Hyalospheniidae (Amoebozoa: Arcellinida). Protist, 159:165-176.

Leidy, J. 1879. Fresh-water Rhizopods of North America. Report of the United States Geological Survey of the Territories, volume 12. Government Printing Office, Washington.

Loeblich, A.R., Jr. and Tappan, H. 1964. Sarcodina, chiefly 'Thecamoebians' and Foraminiferida, p. C1C900. In Moore, R.C. (ed.), Treatise of Invertebrate Paleontology, Part C, Protista 2, Geological Society of America and University of Kansas Press, Boulder, Colorado, and Lawrence, Kansas.

Lühe, M. 1913. Faunistische Untersuchung der Moore Ostpreußens. Schriften Physikalisch-ökonomischen Gesellschaft Königsberg, 54:84-86. (In German)

Macumber, A.L., Patterson, R.T., Roe, H.M., Reinhardt, E.G., Neville, L.A., and Swindles, G.T. 2014. Autecological approaches to resolve subjective taxonomic divisions within Arcellina. Protist, 165:305-316.

Medioli, F.S. and Scott, D.B. 1983. Holocene Arcellina (thecamoebians) from Eastern Canada. Cushman Foundation for Foraminiferal Research Special Publication no. 21. Cushman Foundation, Washington.

Medioli, F.S., Scott, D.B., Collins, E.S., and McCarthy, F.M.G. 1990a. Fossil thecamoebians: present status and prospects for the future, p. 813-840. In Hemleben, C., Kaminski, M.A., Kuhnt, W., and Scott, D.B. (eds.), Paleoecology, Biostratigraphy, Paleoceanography and Taxonomy of Agglutinated Foraminifera. NATO Advanced Study Institute Series, Series C, Mathematical and Physical Sciences, Springer, the Netherlands.

Medioli, F.S., Scott, D.B., Collins, E.S., and Wall, J.H. 1990b. Thecamoebians from the early Cretaceous deposits of Ruby Creek, Alberta (Canada), p. 793812. In Hemleben, C., Kaminski, M.A., Kuhnt, W., and Scott, D.B. (eds.), Paleoecology, Biostratigraphy, Paleoceanography and Taxonomy of Agglutinated Foraminifera. NATO Advanced Study Institute Series, Series C, Mathematical and Physical Sciences, Springer, the Netherlands.

Meisterfeld, R. 2002. Order Arcellinida Kent, 1880, p. 827-860. In Lee, J.J., Leedale, G.F., and Bradbury, P. (eds.), The Illustrated Guide to the Protozoa (second edition). Allen Press, Lawrence, Kansas, USA.

Mitchell, E.A.D. and Meisterfeld, R. 2005. Taxonomic confusion blurs the debate on cosmopolitanism versus local endemism of free-living protists. Protist, 156:263-267. 
Nikolaev, S.I., Mitchell, E.A.D., Petrov, N.B., Berney, C., Fahrni, J., and Pawlowski, J. 2005. The testate lobose amoebae (order Arcellinida Kent, 1880) finally find their home within Amoebozoa. Protist, 156:191202.

Ogden, C.G. 1988. The role of the organic matrix in the construction of the agglutinate shell of Centropyxis discoides. Journal of Natural History, 22:137-148.

Ogden, C.G. and Hedley, R.H. 1980. An Atlas of Fresh Water Testate Amoeba. Oxford University Press, Oxford.

Oliverio, A.M., Lahr, D.J., Nguyen, T., and Katz, L.A. 2014. Cryptic diversity within morphospecies of testate amoebae (Amoebozoa: Arcellinida) in New England bogs and fens. Protist, 165:196-207.

Patterson, R.T. 2014. Mediolus, a new genus of arcellacea (testate lobose amoebae). Palaeontologia Electronica 17.2.28A:8pp, 3MB; palaeo-electronica.org/ content/2014/782-mediolus-new-genus

Patterson, R.T. and Fishbein, E. 1989. Re-examination of the statistical methods used to determine the number of point counts needed for micropaleontological quantitative research. Journal of Paleontology, 63:245-248.

Patterson, R.T., Baker, T., and Burbridge, S.M. 1996. Arcellaceans (thecamoebians) as proxies of arsenic and mercury contamination in northeastern Ontario lakes. Journal of Foraminiferal Research, 26(2):172183.

Patterson, R.T. and Kumar, A. 2002. A review of current testate rhizopod (thecamoebian) research in Canada. Palaeogeography, Palaeoclimatology, Palaeoecology, 180:225-251.

Patterson, R.T., Lamoureux, E.D.R., Neville, L.A., and Macumber, A.L. 2013. Arcellaceans (testate lobose amoebae) as $\mathrm{pH}$ indicators in a pyrite mine acidified lake, northeastern Ontario, Canada. Microbial Ecology, 65:541-554.

Patterson, R.T., MacKinnon, K.D., Scott, D.B., and Medioli, F.S. 1985. Arcellaceans (Thecamoebians) in small lakes of New Brunswick and Nova Scotia: modern distribution and Holocene stratigraphic changes. Journal of Foraminiferal Research, 15:114-137.

Patterson, R.T., Roe, H.M., and Swindles, G.T. 2012. Development of an Arcellacea (testate lobose amoebae) based transfer function for sedimentary phosphorus in lakes. Palaeogeography, Palaeoclimatology, Palaeoecology, 348-349:32-44.

Porter, S.A. and Knoll, A.H. 2000. Testate amoeba in the Neoproterozoic Era: evidence from vase-shaped microfossils in the Chuar Group, Grand Canyon. Paleobiology, 26:360-385.

Reinhardt, E.G., Dalby, A.P., Kumar, A., and Patterson, R.T. 1998. Arcellinans as pollution indicators in mine tailing contaminated lake near Cobalt, Ontario, Canada. Micropaleontology, 44:131-148.

Roe, H.M., Patterson, R.T., and Swindles, G.T. 2010. Controls on the contemporary distribution of lake thecamoebians (testate amoebae) within the Greater Toronto area and their potential as water quality indicators. Journal of Paleolimnology, 43:955-975.

Root, F.M. 1918. Inheritance in the asexual reproduction of Centropyxis aculeata. Genetics, 3:173-206.

Scott, D.B. and Hermelin, J.O.R. 1993. A device for precision splitting of micropaleontological samples in liquid suspension. Journal of Paleontology, 67:151-154.

Scott, D.B. and Medioli, F.S. 1983. Testate rhizopods in Lake Erie: modern distribution and stratigraphic implications. Journal of Paleontology, 57:809-820.

Siemensma, F.J. 2015. Microworld, world of amoeboid organisms. World-wide electronic publication, Kortenhoef, the Netherlands. http://www.arcella.nl/ centropyxis-pontigulasiformis-1; Accessed on 12 January 2015.

Smirnov, A., Nassonova, E., Berney, C., Fahrni, J., Bolivar, I., and Pawlowski, J. 2005. Molecular phylogeny and classification of the Lobose Amoebae. Protist, 156:129-142.

van Hengstum, P.J., Reinhardt, E.G., Medioli, F.S., and Gröcke, D.R. 2007. Exceptionally preserved late Albian (Cretaceous) Arcellaceans (Thecamoebians) from the Dakota Formation near Lincoln, Nebraska, USA. Journal of Foraminiferal Research, 37:300-308.

Vázquez-Riveiros, N., Babalola, A.O., Boudreau, R.E.A., Patterson, R.T., Roe, H.M., and Doherty, C. 2007. Modern distribution of saltmarsh foraminifera and thecamoebians in the Seymour-Belize Inlet Complex, British Columbia, Canada. Marine Geology, 242:3963.

von Stein, S.F.N. 1857. Über die ihm aus eigener Untersuchung bekannt gewordenen Süßwasser-Rhizopoden. Königliche Böhmische Gesellschaft der Wissenschaften Abhandlungen, 5:41-43. (In German)

Wallich, G.C. 1864. On the extent, and some of the principal causes of structural variation among the difflugian rhizopods. Annals and Magazine of Natural History Series 3, 13:215-245.

Wanner, M. 1999. A review on the variability of testate amoebae: methodological approaches, environmental influences and taxonomical implications. Acta Protozoologica, 38:15-29. 